\title{
Thermodynamic Modeling of Sr/TRU Removal
}

\author{
Andrew R. Felmy
}

August 2000

Prepared for BNFL, Inc. under Contract W375-98-LC-4168

Battelle, Pacific Northwest Division Richland, Washington 99352 


\section{DISCLAIMER}

This report was prepared as an account of work sponsored by an agency of the United States Government. Neither the United States Government nor any agency thereof, nor any of their employees, make any warranty, express or implied, or assumes any legal liability or responsibility for the accuracy, completeness, or usefulness of any information, apparatus, product, or process disclosed, or represents that its use would not infringe privately owned rights. Reference herein to any specific commercial product, process, or service by trade name, trademark, manufacturer, or otherwise does not necessarily constitute or imply its endorsement, recommendation, or favoring by the United States Government or any agency thereof. The views and opinions of authors expressed herein do not necessarily state or reflect those of the United States Government or any agency thereof. 


\section{DISCLAIMER}

Portions of this document may be illegible in electronic image products. Images are produced from the best available original document. 


\begin{abstract}
This report summarizes the development and application of a thermodynamic modeling capability designed to treat the Envelope $C$ wastes containing organic complexants. A complete description of the model development is presented. In addition, the model was utilized to help gain insight into the chemical processes responsible for the observed levels of $\mathrm{Sr}$, TRU, $\mathrm{Fe}$, and $\mathrm{Cr}$ removal from the diluted feed from tank 241-AN-107 which had been treated with $\mathrm{Sr}$ and permanganate. Modeling results are presented for $\mathrm{Sr}, \mathrm{Nd}(\mathrm{III}) / \mathrm{Eu}$ (III), $\mathrm{Fe}, \mathrm{Cr}, \mathrm{Mn}$, and the major electrolyte components of the waste (i.e. $\mathrm{NO}_{3}, \mathrm{NO}_{2}, \mathrm{~F}, \ldots$ ). On an overall basis the added $\mathrm{Sr}$ is predicted to precipitate as $\mathrm{SrCO}_{3}(\mathrm{c})$ and the $\mathrm{MnO}_{4}^{-}$reduced by the $\mathrm{NO}_{2}^{-}$and precipitated as a $\mathrm{Mn}$ oxide. These effects result in only minor changes to the bulk electrolyte chemistry, specifically, decreases in $\mathrm{NO}_{2}{ }^{-}$and $\mathrm{CO}_{3}{ }^{2-}$, and increases in $\mathrm{NO}_{3}{ }^{-}$and $\mathrm{OH}$. All of these predictions are in agreement with the experimental observations. The modeling also indicates that the majority of the Sr, TRU's (or $\mathrm{Nd}$ (III)/Eu(III) analogs, and Fe are tied up with the organic complexants. The $\mathrm{Sr}$ and permanganate additions are not predicted to effect these chelate complexes significantly owing to the precipitation of insoluble $\mathrm{Mn}$ oxides or $\mathrm{SrCO}_{3}$. These insoluble phases maintain low dissolved concentrations of $\mathrm{Mn}$ and $\mathrm{Sr}$ which do not affect any of the other components tied up with the complexants. It appears that the removal of the $\mathrm{Fe}$ and TRU's during the treatment process is most likely as a result of adsorption or occlusion on/into the $\mathrm{Mn}$ oxides or $\mathrm{SrCO}_{3}$, not as direct displacement from the complexants into precipitates. Recommendations are made for further studies that are needed to help resolve these issues.
\end{abstract}




\section{CONTENTS}

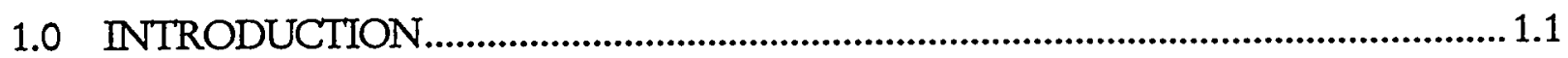

2.0 THERMODYNAMIC MODEL DEVELOPMENT .............................................. 2.1

3.0 APPLICATION TO SR/TRU SEPARATIONS FOR AN-107 DILUTED FEED .........3.1

3.1 Major Electrolyte Components..................................................................... 3.1

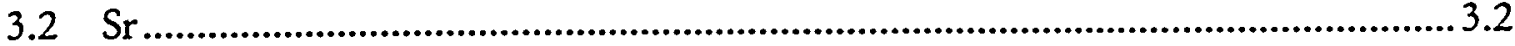

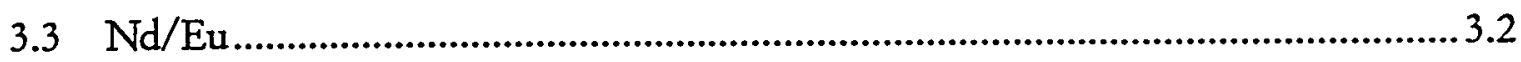

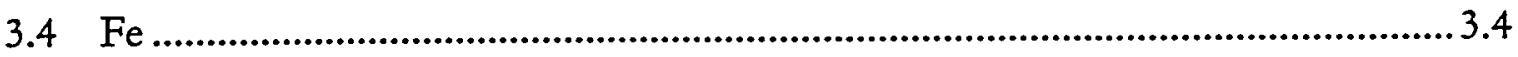

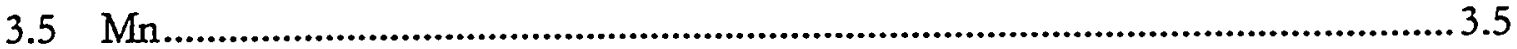

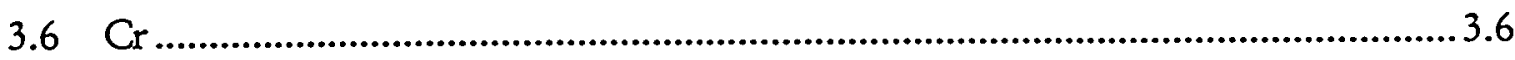

4.0 CONCLUSIONS AND RECOMMENDATIONS .............................................. 4.1

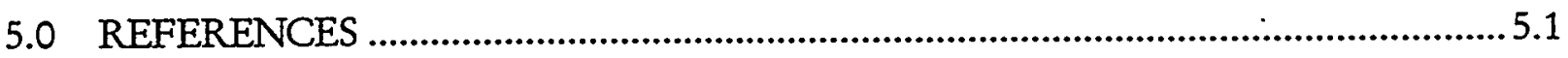




\section{FIGURES}

Figure 3.1. The solubility of $\mathrm{Eu}(\mathrm{OH})_{3}(\mathrm{c})$ in the presence and absence of EDTA as a Function of $\mathrm{NaOH}$ concentration.

\section{TABLES}

Table 2.1. AN-107 Diluted Feed Composition

2.4

Table 2.2. Aqueous Species and Solid Phases Included in the Thermodynamic Model 2.5 


\subsection{INTRODUCTION}

Radioactive wastes stored at Hanford require different levels of pretreatment to meet prespecified limits for low-activity waste or other disposal categories. Wastes currently labeled as Envelope $C$ in the waste treatment privatization contract present difficult challenges in this regard as they contain high levels of organic complexants (e.g. EDTA, HEDTA, NTA, ...) and elevated levels of Sr-90 and transuranics (TRU's). These wastes thus require pretreatment before disposal. Owing to the complex nature of the wastes, developing such pretreatment processes has not been an easy task and different methods have been tested including additions of $\mathrm{Fe}, \mathrm{Sr}$, and permanganate (Hallen et al. 2000).

The objective of this report is to evaluate the potential for thermodynamic modeling to help both in understand the underlying chemical behavior of the wastes and in developing improved pretreatment processes. Unfortunately, currently available waste processing models such as the ESP model (OLI systems 1999), are not applicable to modeling the $\mathrm{Sr}$ /TRU separation process for Envelope $\mathrm{C}$ wastes. For example, using the ESP model for calculating the solubility of $\mathrm{SrCO}_{3}(\mathrm{c})$ (a phase which readily forms in the treatment process) is in error by two orders of magnitude (i.e. $10^{-7} \mathrm{~m}$ calculated versus $10^{-5} \mathrm{~m}$ experimental) even in a very simple solution $\left(1.0 \mathrm{~m} \mathrm{Na}_{2} \mathrm{CO}_{3}\right)$ as a result of the neglect of $\mathrm{Sr}-\mathrm{CO}_{3}$ complexes. Modeling the solubility of the TRU's is also problematic in the current version (6.2) of the code. For example, the solubility of $\mathrm{Am}(\mathrm{OH})_{3}(\mathrm{c})$ is off by five orders of magnitude even in a simple $0.5 \mathrm{~m} \mathrm{NaOH}$ solution (i.e. predicted $>10^{-3} \mathrm{~m}$, experimental $10^{-8} \mathrm{~m}$ ) principally as the result of an unusually large stability for the neutral species, $\operatorname{Am}(\mathrm{OH})_{3}(\mathrm{aq})$. The situation does not improve if the trivalent actinides are modeled using an analog approach (i.e. $\mathrm{Nd}(\mathrm{III})$ or $\mathrm{Eu}$ (III)). In this case the solubilities are still in error by approximately five orders of magnitude, but interestingly, the reasons for the error are different. In the case of $\mathrm{Eu}$ (III) and $\mathrm{Nd}$ (III) the error results from an unusually strong equilibrium constant for the fourth hydrolysis constant (i.e. $\mathrm{Eu}(\mathrm{OH})_{4}$ or $\mathrm{Nd}(\mathrm{OH})_{4}{ }^{2}$ ) whereas the stability constant for the neutral species appears fine. Clearly, currently available versions of the ESP model (OLI 1999) are inapplicable to evaluating the Sr/TRU separation process from envelope $C$ wastes.

With these factors in mind, this project has been divided into two efforts. The first effort focused on constructing a realistic thermodynamic model for the envelope $\mathrm{C}$ waste types. The second effort applied this model to evaluating the Sr/TRU separation process using the An- 
107 diluted feed solution treated experimentally by Hallen et al. (2000). The first effort utilized the Pitzer thermodynamic model since we have recently completed a database for both the inorganic reactions (Felmy and Rai 1999) as well as for the chelate complexes (Felmy et al. 2000), which is applicable to the trivalent actinides. In addition, we have also developed a thermodynamic model for Sr valid to high base and carbonate concentration (Felmy et al. 1998; Felmy and Mason 1998). Thus we will begin with the development of the Pitzer thermodynamic model. An analysis of the results for the diluted AN-107 feed follows the description of the thermodynamic model. 


\subsection{THERMODYNAMIC MODEL DEVELOPMENT}

The aqueous thermodynamic model used in this study is the ion-interaction model of Pitzer and coworkers. (Pitzer, 1973; Pitzer, 1991) This model emphasizes a detailed description of the specific ion interactions in the solution. The effects of the specific ion interactions on the excess solution free energy are contained within the expressions for the activity coefficients. The activity coefficients can be expressed in a virial-type expansion as

$$
\ln \gamma_{\mathrm{i}}=\ln \gamma_{\mathrm{i}}^{\mathrm{DH}}+\sum_{\mathrm{j}} \beta_{\mathrm{ij}}(\mathrm{I}) \mathrm{m}_{\mathrm{j}}+\sum_{\mathrm{j}} \sum_{\mathrm{k}} \mathrm{C}_{\mathrm{ijk}} \mathrm{m}_{\mathrm{j}} \mathrm{m}_{\mathrm{k}}+\ldots
$$

where $\mathrm{m}$ is the molality and $\gamma_{\mathrm{i}}^{\mathrm{DH}}$ is a modified Debye-Hückel activity coefficient that is a universal function of ionic strength. $\beta_{\mathrm{ij}}(\bar{I})$ and $\mathrm{C}_{\mathrm{ijk}}$ are specific for each ion interaction and are a function of ionic strength. Pitzer gives explicit phenomenological expressions for the ionic-strength dependence of $\beta$. (Pitzer, 1973; Pitzer, 1991). The third virial coefficient, $C$, is taken to be independent of ionic strength. The form of $\beta$ is different for like, unlike, and neutral ion interactions. A detailed description of the exact form of Eq. (1) is given elsewhere. (Felmy and Weare, 1986; Felmy et al. 1989; Harvie et al. 1984).

In order to establish the model parameters needed for this study we must first define the nature of the chemical system that is to be modeled. In this regard, the chemical composition of the diluted waste feed for tank AN-107 is shown in Table 2.1. The principal electrolyte components include $\mathrm{Na}, \mathrm{OH}, \mathrm{NO}_{3}, \mathrm{NO}_{2}, \mathrm{CO}_{3}, \mathrm{~F}, \mathrm{PO}_{4}, \mathrm{Al}(\mathrm{OH})_{4}$, and $\mathrm{SO}_{4}$. This is precisely the chemical system for which we (Felmy et al. 1994a) have developed a Pitzer thermodynamic model over the temperature range $25-100^{\circ} \mathrm{C}$. This model includes all of the essential binary ion-interactions (i.e. $\mathrm{Na}^{+}-\mathrm{OH}, \mathrm{Na}^{+}-\mathrm{NO}_{3}{ }^{-}, \ldots$ ), important ion associations (i.e. formation of $\mathrm{NaNO}_{3}(\mathrm{aq})$ and $\mathrm{NaNO}_{2}(\mathrm{aq})$ ion pairs), necessary common-ion ternary interactions (i.e. $\mathrm{NO}_{3}^{-}$$\mathrm{Al}(\mathrm{OH})_{4} ; \mathrm{Na}^{+}-\mathrm{NO}_{3}-\mathrm{Al}(\mathrm{OH})_{4} ; \ldots$ ) and solid phases (see Table 2.2). A complete description of these model parameters along with extensive comparisons with the existing osmotic and solubility data is given in Felmy et al. (1994a). It is worthy of note that the model does not include data for the formation of certain mixed double salts, most importantly mixed Na-F-PO solids that have recently been shown in the tank solutions. Adding the necessary data for such solids remains a task for subsequent years. 
With the thermodynamic model for the major electrolytes established the necessary data for the other important "minor" components must be established. The components included in the model include all of those in Table 2.1 designated with an asterisk. The metals/cations considered include $\mathrm{Ba}, \mathrm{Ca}, \mathrm{Cr}, \mathrm{Fe}, \mathrm{La}, \mathrm{Mn}, \mathrm{Nd}, \mathrm{Ni}$, and $\mathrm{Sr}$. Sr is included owing to the obvious importance of $\mathrm{Sr}-90$ in the separation process. $\mathrm{Nd}$ and La serve as analogs for the trivalent actinides $\mathrm{Am}$ (III) and $\mathrm{Cm}$ (III). $\mathrm{Ba}$ and $\mathrm{Ca}$ are possible important cations that can compete with Sr for the organic chelates as well as being involved in sulfate/carbonate precipitation reactions. $\mathrm{Fe}$ and $\mathrm{Mn}$ are important in reactions with the gluconate $(\mathrm{Fe})$ and in redox processes $(\mathrm{Mn}) . \mathrm{Mn}$ is also important as a chemical additive (as $\left.\mathrm{MnO}_{4}\right) . \mathrm{Cr}$ is important from an oxidation/reduction perspective and $\mathrm{Ni}$ is present as sufficient concentration and can form potentially important mixed metal-chelate-hydroxy complexes that can tie up the organic chelates. While some of the other components could conceivably be important under unusual conditions these components appeared to be the most likely to be relevant to the $\mathrm{Sr} / \mathrm{TRU}$ precipitation process and were included this year.

The organic chelates included are: gluconate, EDTA, and HEDTA. Only selected data were included for NTA. The concentrations of the chelates were not directly reported by Hallen et al. 2000 and were estimated from the $9 \mathrm{M}$ simulant data. This constraint effects the model calculations described in the next section. However, even with some uncertainty in the actual chelate concentrations the high thermodynamic stability of the gluconate, EDTA and HEDTA complexes makes their selection for inclusion in the model reasonable.

A complete list of the complexes for which thermodynamic data (including stability constants and ion-interaction parameters) are included is given in Table 2.2.

Experimentally measured Pitzer ion-interaction parameters were available for only a few of the species listed in Table 2.2 and analogs were used for many of these parameters as described below. Experimentally determined values were available for the metal ions (i.e. $\mathrm{Sr}^{2+}$, $\mathrm{Ca}^{2+}, \mathrm{Ni}^{2+}, \ldots$ ) with $\mathrm{NO}_{3}^{-}$from Pitzer (1991). The corresponding parameters with $\mathrm{NO}_{2}^{-}$were generally unavailable (except for $\mathrm{Na}^{+}$) and were set equal to the $\mathrm{NO}_{3}^{-}$parameters. The parameters for $\mathrm{Na}^{+}$interactions with $\mathrm{Cr}(\mathrm{OH})_{4}^{-}$were determined by Felmy et al. (1994b) and those for $\mathrm{CrO}_{4}{ }^{2}$ by Pitzer (1991). The parameters for $\mathrm{Na}^{+}$interactions with $\mathrm{Nd} / \mathrm{Eu}(\mathrm{OH})_{4}{ }^{-}$were set equal to the values for $\mathrm{Na}^{+}-\mathrm{Al}(\mathrm{OH})_{4}{ }_{4}$ and tested by Felmy et al. (2000). The parameters for the $\mathrm{Na}^{+}$interactions with the fourth hydrolysis species (i.e. $\mathrm{Mn}(\mathrm{OH})_{4}{ }^{2}, \mathrm{Fe}(\mathrm{OH})_{4}{ }^{2-}, \ldots$ ) were set equal to the measured values (Rai et al. 1991a) for $\mathrm{Cd}(\mathrm{OH})_{4}{ }^{2}$. Similarily, the values for the $\mathrm{Na}^{+}$ interactions with the dicarbonate metal complexes (i.e. $\left.\mathrm{Fe}\left(\mathrm{CO}_{3}\right)_{2}{ }^{2-}, \mathrm{Cu}\left(\mathrm{CO}_{3}\right)_{2}{ }^{2-}\right)$ were set equal to 
the measured values (Rai et al. 1991b) for $\mathrm{Cd}\left(\mathrm{CO}_{3}\right)_{2}{ }^{2-}$. The values for $\mathrm{Na}^{+}$interactions with $\mathrm{Ca}\left(\mathrm{CO}_{3}\right)_{2}{ }_{2}{ }^{2}$ and $\mathrm{Sr}\left(\mathrm{CO}_{3}\right)_{2}{ }^{2-}$, as well as $\mathrm{Sr}^{2+}-\mathrm{OH}^{-}$were experimentally determined by Felmy et al. 1998. The parameters for $\mathrm{Na}^{+}$with $\mathrm{Nd} / \mathrm{Eu}\left(\mathrm{CO}_{3}\right)_{3}{ }^{3}$ are from Felmy and Rai (1999). The values for the organic chelate complexes were estimated using the charge analog approach of Felmy et al. (2000). In this approach the experimentally measured values for $\mathrm{Na}^{+}$with EDTA, HEDTA $^{3-}$,H2EDTA2- and HEDTA- (Pokrovsky et al. 1998) were used for all EDTA and HEDTA species of the same charge (i.e. the parameters for $\mathrm{Na}^{+}$with $\mathrm{H}_{2} \mathrm{EDTA}^{2-}$ were set equal to the parameters for $\mathrm{CaEDTA}^{2-}, \mathrm{NiEDTA}^{2-}$ etc. and the parameters for $\mathrm{HEDTA}^{3-}$ were set equal to the corresponding $\mathrm{Na}^{+}$interaction parameters for $\left.\mathrm{NiOHEDTA}{ }^{3}\right)$. The parameters for $\mathrm{Na}+$ interactions with $\mathrm{EuOH}(\mathrm{NTA})_{3}{ }^{4}$ were experimentally determined by Felmy et al. (2000). 
Table 2.1. AN-107 Diluted Feed Composition

\begin{tabular}{|c|c|c|c|c|c|}
\hline Major Compounds & Concentration (m) & Minor Components & Concentration (m) & Organic Ligands ( $* *)$ & Concentration (m) \\
\hline $\mathrm{Na}^{+}$ & 8.9 & ${ }^{*} \mathrm{Al}$ & $1.7 \times 10^{-1}$ & Glycolate & .30 \\
\hline $\mathrm{NO}_{3}$ & 3.1 & ${ }^{* \mathrm{~B}_{2}}$ & $3.4 \times 10^{-5}$ & Gluconate ${ }^{(*)}$ & .022 \\
\hline $\mathrm{NO}_{2}^{-}$ & 1.3 & ${ }^{*} \mathrm{Ca}$ & $1.3 \times 10^{-2}$ & Citrate & .055 \\
\hline $\mathrm{CO}_{3}{ }^{2-}$ & 1.6 & $\mathrm{Ce}$ & $2.3 \times 10^{-4}$ & EDTA(*) & .024 \\
\hline $\mathrm{OH}$ & 0.84 & $\mathrm{Cd}$ & $4.9 \times 10^{-4}$ & HEDTA $(*)$ & .0094 \\
\hline $\mathrm{SO}_{4}^{2-}$ & 0.1 & ${ }^{*} \mathrm{Cr}$ & $3.3 \times 10^{-3}$ & $\operatorname{NTA}(4)$ & .037 \\
\hline $\mathrm{PO}_{4}^{3}$ & 0.037 & $\mathrm{Cs}$ & $1.1 \times 10^{-4}$ & IDA & .056 \\
\hline ***F. & 0.39 & $\mathrm{Cu}$ & $3.9 \times 10^{-4}$ & & \\
\hline $\mathrm{Cl} \cdot$ & 0.046 & ${ }^{*} \mathrm{Fe}$ & $2.4 \times 10^{-2}$ & & \\
\hline & & $\overline{\mathrm{K}}$ & $3.8 \times 10^{-2}$ & & \\
\hline & & ${ }^{*} \mathrm{La}$ & $1.9 \times 10^{-4}$ & & \\
\hline & & $* M n$ & $2.3 \times 10^{-3}$ & & \\
\hline & & *Nd & $5.8 \times 10^{-4}$ & & \\
\hline & & ${ }^{*} \mathrm{Ni}$ & $7.9 \times 10^{-3}$ & & \\
\hline & & $\mathrm{Pb}$ & $1.45 \times 10^{-3}$ & & \\
\hline & & ${ }^{*} \mathrm{Sr}_{\mathrm{r}}$ & $3.5 \times 10^{-5}$ & & \\
\hline & & $\mathrm{U}$ & $3.6 \times 10^{-4}$ & & \\
\hline & & $\mathrm{Zn}$ & $3.4 \times 10^{-4}$ & & \\
\hline & & $\overline{Z_{r}}$ & $5.6 \times 10^{-4}$ & & \\
\hline
\end{tabular}

* metals for which thermodynamic data were included

\%* estimated from 9M simulant (SRTC 1999), assuming perfect dilution (i.e. 0.856) .

$* *$ IC analysis probably includes formate and acetate 
Table 2.2. Aqueous Species and Solid Phases Included in the Thermodynamic Model

\begin{tabular}{|c|c|c|c|c|}
\hline Component & Aqueous S & & Solid Phases & References \\
\hline Aluminum & $\begin{array}{l}\text { OF. } \\
\text { EDTA } \\
\text { HEDTA } \\
\text { gluconate }\end{array}$ & 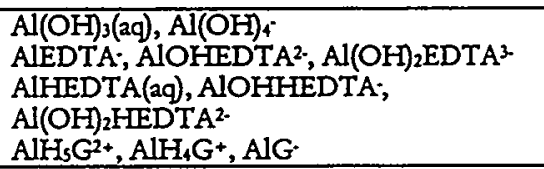 & gibbsite, boehmite & $\begin{array}{l}\text { hydroxide complexes - Felmy } \\
\text { et al. (1994a), others Smith and } \\
\text { Martell (1995) }\end{array}$ \\
\hline Barium & $\begin{array}{l}\mathrm{SO}_{4}^{2-} \\
\mathrm{CO}_{3}^{2-} \\
\text { EDTA } \\
\text { HEDTA }\end{array}$ & $\begin{array}{l}\mathrm{Ba}^{2+} \\
\mathrm{BaSO}_{4}(\mathrm{aq}) \\
\mathrm{BaCO}_{3}(\mathrm{aq}) \\
\mathrm{BaEDTA}^{2-} \\
\mathrm{BaHEDTA}^{-}\end{array}$ & barite, witherite & Smith and Martell (1995) \\
\hline Calcium & $\begin{array}{l}\text { EDTA } \\
\text { HEDTA } \\
\text { gluconare } \\
\mathrm{CO}_{3}^{2-}\end{array}$ & $\begin{array}{l}\mathrm{Ca}^{2+} \\
\mathrm{CaEDTA}^{2+} \\
\mathrm{CaHEDTA}^{2} \\
\mathrm{CaH}_{5} \mathrm{GG}^{+} \\
\mathrm{C}_{2} \mathrm{CO}_{3}(\mathrm{aq}), \mathrm{C}_{2}\left(\mathrm{CO}_{3}\right)_{2}{ }^{2-}\end{array}$ & $\begin{array}{l}\text { calcite, anhydrite, gypsum, gaylussite, } \\
\text { pirssonite, portlandite }\end{array}$ & $\begin{array}{l}\text { carbonate complexes - Felmy } \\
\text { et al. (1998), solid phases - } \\
\text { Harvie et al. (1984), others - } \\
\text { Smith and Martell (1995) }\end{array}$ \\
\hline Chromium & $\begin{array}{l}\text { EDTA } \\
\text { OH. }\end{array}$ & $\begin{array}{l}\mathrm{CrO}_{4}{ }^{2 *} \\
\mathrm{CrEDTA} ; \mathrm{CrOHEDTA}^{2 \cdot} \\
\mathrm{Cu}(\mathrm{OH})_{4}, \mathrm{NaCr}(\mathrm{OH})_{4}(\mathrm{aq})\end{array}$ & $\mathrm{Cr}(\mathrm{OH})_{3}(\mathrm{am})$ & $\begin{array}{l}\text { Felmy et al. (1994b), EDTA - } \\
\text { Smith and Martell (1995) }\end{array}$ \\
\hline Iron(III) & $\begin{array}{l}\text { OH: } \\
\mathrm{CO}_{3}^{2} \text {. } \\
\text { EDTA } \\
\text { HEDTA } \\
\text { gluconate }\end{array}$ & 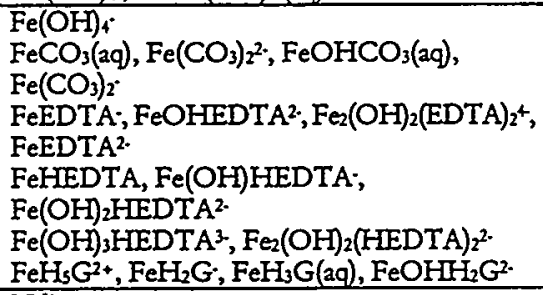 & $\mathrm{Fe}(\mathrm{OH})_{3}(\mathrm{am})$, goethite, hematite & $\begin{array}{l}\text { Fe(II) carbonates - Bruno et al. } \\
\text { (1992b), Fe(III) carbonates - } \\
\text { Bruno et al. (1992a), all others } \\
\text { Smith and Martell (1995) }\end{array}$ \\
\hline $\begin{array}{l}\text { Lanthanum/ } \\
\text { Neodynium }\end{array}$ & $\begin{array}{l}\text { OH: } \\
\mathrm{CO}^{2 *} \\
\text { EDTA } \\
\text { HEDTA } \\
\text { gluconate } \\
\text { NTA }\end{array}$ & 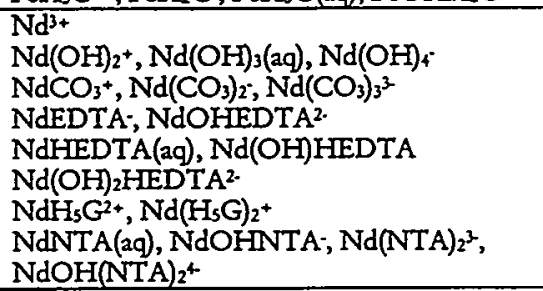 & $\begin{array}{l}\mathrm{Nd}(\mathrm{OH})_{3}, \mathrm{NdOHCO}_{3}, \\
\mathrm{NaNd}\left(\mathrm{CO}_{3}\right)_{2} \bullet 6 \mathrm{H} 2 \mathrm{O}\end{array}$ & $\begin{array}{l}\text { hydroxide and carbonate } \\
\text { complexes - Felmy and Rai } \\
\text { (1995), EDTA, HEDTA, NTA } \\
\text { - Felmy et al. (2000), gluconate } \\
\text { - Martell and Smith (1995), } \\
\text { solids - Rao et al. (1996a,b) }\end{array}$ \\
\hline Manganese & $\begin{array}{l}\text { OH- } \\
\text { EDTA } \\
\text { HEDTA }\end{array}$ & $\begin{array}{l}\mathrm{Mn}^{2+} \\
\mathrm{MnOH}^{+}, \mathrm{Mn}(\mathrm{OH})_{4}^{2-} \\
\mathrm{MnEDTA}^{2-} \\
\text { MnHEDTA }\end{array}$ & $\mathrm{Mn}(\mathrm{OH})_{2}, \mathrm{MnCO}_{3}$ & Martell and Smith (1995) \\
\hline Nickel & $\begin{array}{l}\text { OH: } \\
\mathrm{CO}_{3}^{2-} \\
\text { EDTA } \\
\text { HEDTA } \\
\text { gluconate }\end{array}$ & $\begin{array}{l}\mathrm{Ni}^{2+} \\
\mathrm{NiOH}^{+} \\
\mathrm{NiCO}_{3}(\mathrm{aq}) \\
\mathrm{NiEDTA}^{2-}, \mathrm{NiOHEDTA}^{3} \\
\mathrm{NiHEDTA}^{-} \\
\mathrm{NiH}_{3} \mathrm{G}^{+}, \mathrm{N}_{23} \mathrm{HG}^{-}\end{array}$ & $\mathrm{Ni}(\mathrm{OH})_{2}, \mathrm{NiCO}_{3}$ & $\begin{array}{l}\text { Hydroxides - Mattigod et al. } \\
\text { (1997), others - Martell and } \\
\text { Smith (1995) }\end{array}$ \\
\hline Sodium & $\begin{array}{l}\mathrm{NO}_{3} \\
\mathrm{NO}_{2}\end{array}$ & $\begin{array}{l}\mathrm{Na}_{2}^{+} \\
\mathrm{NaNO}_{3} \\
\mathrm{NaNO}_{2}\end{array}$ & $\begin{array}{l}\mathrm{NaNO}_{3}, \mathrm{NaNO}_{2}, \mathrm{NaF}, \\
\mathrm{Na}_{3} \mathrm{PO}_{4} \bullet 8 \mathrm{H}_{2} \mathrm{O}, \mathrm{Na}_{3} \mathrm{PO}_{4} \bullet 10 \mathrm{H}_{2} \mathrm{O}, \\
\mathrm{Na}_{3} \mathrm{PO}_{4} \bullet 12 \mathrm{H}_{2} \mathrm{O}, \mathrm{Na}_{2} \mathrm{CO}_{3} \bullet 2 \mathrm{Na}_{2} \mathrm{SO}_{4}, \\
\mathrm{Na}_{2} \mathrm{SO}_{4} \cdot \mathrm{CaSO}_{4}, \\
\mathrm{CaSO}_{4} \cdot 2 \mathrm{Na}_{2} \mathrm{SO}_{4} \cdot 2 \mathrm{H}_{2} \mathrm{O}, \\
\mathrm{Na}_{2} \mathrm{SO}_{4} \bullet 10 \mathrm{H}_{2} \mathrm{O}, \mathrm{Na}_{2} \mathrm{CO}_{3} \bullet 10 \mathrm{H}_{2} \mathrm{O}, \\
\mathrm{Na}_{2} \mathrm{CO}_{3} \bullet 7 \mathrm{H}_{2} \mathrm{O}, \mathrm{Na}_{2} \mathrm{SO}_{4}, \\
\mathrm{Na}_{2} \mathrm{CO}_{3} \bullet \mathrm{H}_{2} \mathrm{O}\end{array}$ & $\begin{array}{l}\text { Felmy et al. (1994a), } \\
\mathrm{CaSO}_{4} \cdot 2 \mathrm{Na}_{2} \mathrm{SO}_{4} \cdot 2 \mathrm{H}_{2} \mathrm{O}- \\
\text { Harvie et al. }(1984)\end{array}$ \\
\hline Strontium & $\begin{array}{l}\mathrm{CO}_{3}^{2-} \\
\text { EDTA } \\
\text { HEDTA } \\
\text { gluconate }\end{array}$ & $\begin{array}{l}\mathrm{Sr}^{2+} \\
\mathrm{SrCO}_{3}(\mathrm{aq}), \mathrm{Sr}\left(\mathrm{CO}_{3}\right)_{2^{2-}} \\
\mathrm{SrEDTA}^{2 *} \\
\mathrm{SrHEDTA}^{-} \\
\mathrm{SrH}_{5} \mathrm{G}^{+}\end{array}$ & $\mathrm{Sr}(\mathrm{OH})_{2} \bullet 8 \mathrm{H}_{2} \mathrm{O}, \mathrm{SrCO}_{3}, \mathrm{SrSO}_{4}$ & $\begin{array}{l}\text { carbonates - Felmy et al. } \\
\text { (1998), others - Martell and } \\
\text { Smith (1995) }\end{array}$ \\
\hline
\end{tabular}




\subsection{APPLICATION TO SR/TRU SEPARATIONS FOR AN-107 DILUTED FEED}

In this section the thermodynamic model that we have developed is applied to help gain a better understanding of the chemical processes that take place when the $\mathrm{AN}-107$ diluted feed is subjected to permanganate and $\mathrm{Sr}$ additions. The experimental studies are described in Hallen et al. 2000. Briefly, the diluted AN-107 feed (dissolved component concentrations estimated in Table 2.1) was subjected to the addition of permanganate and stable $\mathrm{Sr}$ to concentrations of $0.05 \mathrm{M}$ and $0.075 \mathrm{M}$ respectively. These chemical additions significantly altered the waste composition and resulted in the removal $\mathrm{Fe}, \mathrm{Cr}, \mathrm{Mn}$, and trivalent actinides and analogs $(\mathrm{Nd} / \mathrm{Eu})$. The total dissolved $\mathrm{Sr}$ concentration increased upon addition but the removal of radioactive Sr-90 increased.

The model simulations were initiated using the dissolved aqueous concentrations shown in Table 2.1 and then the permanganate and Sr introduced to identify changes in equilibria. The results will be described for the major ions followed by the results for $\mathrm{Sr}, \mathrm{Nd} / \mathrm{Eu}$ (the trivalent actinide analogs), $\mathrm{Fe}, \mathrm{Mn}$, and $\mathrm{Cr}$.

\subsection{Major Electrolyte Components}

The results for the major electrolytes before treatment show that all of the components are soluble with the exception of fluoride. Approximately half of the fluoride is predicted to precipitate as $\mathrm{NaF}$ (c). The prediction of $\mathrm{NaF}$ (c) precipitation also agrees with simulations run by ESP. However, ESP also predicts the formation of $\mathrm{Na}_{3} \mathrm{FSO}_{4}(\mathrm{c})$ and $\mathrm{Na} 7 \mathrm{~F}(\mathrm{PO} 4)_{2} \cdot 19 \mathrm{H}_{2} \mathrm{O}$, solids that are not in the Pitzer database. It thus appears that the analytical fluoride concentration is too high. This is probably a result of the analytical procedure used to determine fluoride (IC), which can include acetate and formate as well as fluoride. The Pitzer model also predicts that the solutions are saturated with respect to $\mathrm{Al}(\mathrm{OH})_{3}$ (i.e. gibbsite). Though this fact does not impact the current pretreatment process since the hydroxide concentration actually increases as a result of $\mathrm{MnO}_{4}^{-}$reduction (see below). Other treatment processes, such as dilution of the AN107 feed to $6 \mathrm{M} \mathrm{Na}$ and1.0M hydroxide also moves the solution composition away from the gibbsite phase boundary. Never the less it is something to be aware of should the pretreatment process be modified. 
Among the major components, only nitrite, carbonate, and hydroxide are altered by the treatment process. Carbonate is lowered by the precipitation of $\mathrm{SrCO}_{3}(\mathrm{c})$ and nitrite is oxidized to nitrate by the added $\mathrm{MnO}_{4}$;

$$
2 \mathrm{MnO}_{4}^{-}+3 \mathrm{NO}_{2}^{-}+2 \mathrm{H}_{2} \mathrm{O} \rightarrow 2 \mathrm{MnO}_{2}(\mathrm{c})+3 \mathrm{NO}_{3}^{-}+2 \mathrm{OH}^{-}
$$

This reaction also results in generation of hydroxide, which prevents any gibbsite precipitation. The removal of the $\mathrm{Mn}$ and the decrease in nitrite agree with the experimental observations. The details on the $\mathrm{Mn}$ changes are described below.

\section{$3.2 \mathrm{Sr}$}

In the solutions before treatment the $\mathrm{Sr}$ appears to be tied up with the organic complexants (e.g. SrEDTA ${ }^{2}$ ). Although the carbonate concentration is very high the aqueous carbonate complexes (Table 2.2) are not strong enough to account for the initial observed dissolved $\mathrm{Sr}$ concentration. However when the organic complexants are considered in the calculations the $\mathrm{Sr}$ solubilizes and $\mathrm{SrCO}_{3}(c)$ becomes undersaturated. This initial undersaturation agrees with the experimental observations of the diluted feed, which shows increases in total dissolved $\mathrm{Sr}$ concentration (i.e. negative decontamination factors for total $\mathrm{Sr}$ ). The modeling indicates that this results from organic chelate complexes rather than inorganic carbonate complexation. The addition of large amounts of added $\mathrm{Sr}$ in the treatment process then "saturates" the chelate complexes and $\mathrm{SrCO}_{3}(c)$ precipitates. It should be noted that this chelate "saturation" does not mean that all of the chelates are tied up with Sr. In fact only a few percent of the organic complexants are tied up with Sr owing to the low solubility of $\mathrm{SrCO}_{3}(\mathrm{c})$.

\subsection{Nd/Eu}

$\mathrm{Nd}$ (III) and $\mathrm{Eu}$ (III) are analogs for the trivalent actinides $\mathrm{Am}$ (III) and $\mathrm{Cm}$ (III). Recent experimental data (Felmy et al. 2000) have shown that in the presence of organic complexants and high base concentration that mixed metal-chelate-hydroxide complexes (i.e. EuOHEDTA ${ }^{2}$, $\left.\mathrm{EuOH}(\mathrm{NTA})_{2}{ }^{4}, \ldots\right)$ result in significant increases in the solubility of the stable hydroxide phases, see Figure 3.1. 


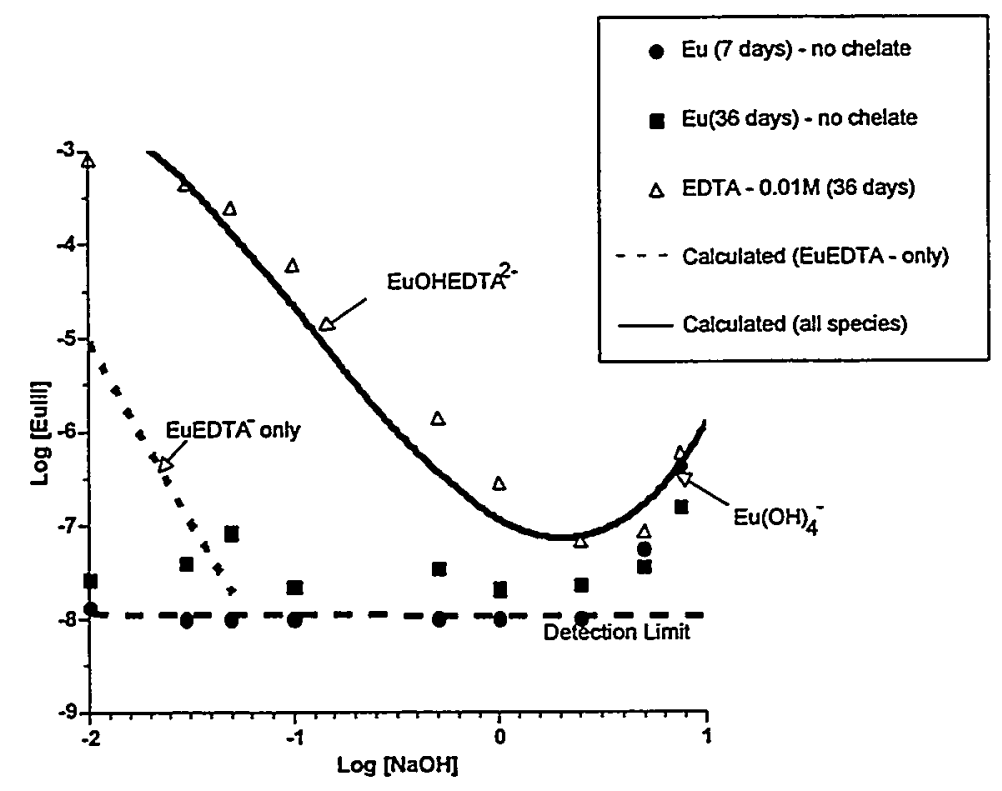

Figure 3.1. The solubility of $\mathrm{Eu}(\mathrm{OH})_{3}(\mathrm{c})$ in the presence and absence of EDTA as a Function of $\mathrm{NaOH}$ concentration.

However, even with these complexes included in the model, the results indicate that $\mathrm{Eu}(\mathrm{OH})_{3}$ or $\mathrm{Nd}(\mathrm{OH})_{3}$ should precipitate from solution. The model predicts a solubility of approximately $10^{-5} \mathrm{~m}$, which seems reasonable in comparison with the data shown in Figure 3.1. However the analytical data for $\mathrm{Nd}$ before treatment shows a dissolved concentration approximately an order of magnitude greater than the model predictions. The differences could result from a variety of factors: analytical error in determining solution compositions, incomplete solids separation, or an error in the thermodynamic model. The latter effect is possible especially considering that the thermodynamic model was developed in pure $\mathrm{NaOH}$ solutions. Mixing terms with the other species present in the diluted feed (e.g. model parameters 
for interactions such as $\left.\mathrm{NO}_{3}^{-}-\mathrm{Eu}(\mathrm{OH}) \mathrm{EDTA}^{2-}, \mathrm{NO}_{2}^{-}-\mathrm{Eu}(\mathrm{OH}) \mathrm{EDTA}^{2}\right)$ could account for these differences. Alternatively, the high carbonate concentration could be resulting in the formation of mixed Eu-EDTA- $\mathrm{CO}_{3}$ complexes in analogy with the Eu-OH-EDTA complexes. This latter possibility could also explain the removal of Am when carbonate concentrations are lowered. Experimental studies with individual chelates and thermodynamic measurements in mixed electrolyte systems (including carbonate) would be required to identifying the discrepancy.

The simulations performed following treatment do not significantly alter the situation. The added $\mathrm{Sr}$ is not effective in displacing $\mathrm{Nd} / \mathrm{Eu}$ from the chelate complexes since the carbonate concentration keeps $\mathrm{Sr}$ insoluble as $\mathrm{SrCO}_{3}(\mathrm{c})$ and the added $\mathrm{Mn}$ is removed as a $\mathrm{Mn}$ oxide. If the model is "correct" such results indicate that the removal of $\mathrm{Am} / \mathrm{Cm} / \mathrm{Eu}$ upon treatment is not a result of metal ion displacement reactions among the chelates but more likely as the result of an adsorption or occlusion of the trivalents in the precipitated manganese oxides or $\mathrm{SrCO}_{3}(\mathrm{c})$. This latter conclusion is also partially supported by the experimental data for the actinides themselves (i.e. Am-241, Cm-242, and $\mathrm{Cm}-243+\mathrm{Cm}-244$. These radionuclides are present at quite low concentrations (i.e. Am-241 $\left(5.7 \times 10^{-7} \mathrm{~m}\right), \mathrm{Cm}-242\left(2.1 \times 10^{-12} \mathrm{~m}\right), \mathrm{Cm}-243+$ $\left.\mathrm{Cm}-244\left(7.3 \times 10^{-12} \mathrm{~m}\right)\right)$. These concentrations are far below any predicted solubility equilibrium with respect to the hydroxide phases, yet they also show significant decontamination factors ( 30 - 66). In addition the data for $\mathrm{Eu}(\mathrm{III})$, which is present at quite low concentration, ${ }^{\sim} 2 \times 10^{-8} \mathrm{M}$, also shows a significant DF (11-12). Hence the removal of the trivalent actinides and actinide analogs ( $\mathrm{Eu}$ (III) can occur at concentrations well below the solubility limits strongly indicating that adsorption reactions with the bulk precipitated manganese oxides and/or $\mathrm{SrCO}_{3}$ is a likely mechanism. Adsorption of Am-241 on precipitated manganese oxides has been previously hypothesized as a removal mechanism from AN-107 simulants (SRTC 1999).

\section{$3.4 \quad \mathrm{Fe}$}

The modeling results for $\mathrm{Fe}$ in the initial diluted feed indicate that the iron should be present as a soluble $\mathrm{Fe}(\mathrm{III})$-hydroxyl-gluconate complex (designated $\mathrm{Fe}(\mathrm{OH}) \mathrm{H}_{2} \mathrm{G}^{2}$ in Table 2.2). All $\mathrm{Fe}$ (II) complexes, including EDTA complexes and $\mathrm{CO}_{3}{ }^{2 \cdot}$ complexes are insignificant, at least if $\mathrm{NO}_{2}^{-} / \mathrm{NO}_{3}^{-}$equilibria is maintained. The $\mathrm{NO}_{2}^{-} / \mathrm{NO}_{3}^{-}$equilibrium assumption is discussed further in the $\mathrm{Mn}$ section that follows. The addition of the $\mathrm{Sr}$ and permanganate does not alter this situation. The added $\mathrm{Sr}$ and $\mathrm{Mn}$ do not compete for the gluconate complex and the Fe(III) 
present in solution cannot be oxidized further. Therefore, the observed removal of $F e$ is either the result of a lack of redox equilibria between $\mathrm{NO}_{2}{ }^{-} / \mathrm{NO}_{3}{ }^{-}$resulting in an initial presence of $\mathrm{Fe}$ (II), selective oxidation of the gluconate complexes, or adsorption of the $\mathrm{Fe}$ (III)-gluconate complexes to the precipitated $\mathrm{Mn}$ and $\mathrm{Sr}$ phases. Thermodynamic modeling cannot shed any more light on these issues until more data is available on the specific chemical effects of the treatment process (e.g. change in individual chelate concentrations, nature of the solid compounds precipitated).

\section{5 $\mathrm{Mn}$}

The chemical behavior of $\mathrm{Mn}$ is particularly interesting since it both redox sensitive and is part of the chemical additions used to help remove the Sr and TRU's. Experimentally, $\mathrm{Mn}$ is added to the simulant as $\mathrm{Mn}(\mathrm{II})$ and remains soluble until the addition of $\mathrm{Sr}$ and $\mathrm{MnO}_{4}^{-}$, whereupon $\mathrm{Mn}$ precipitates from solution, presumably as $\mathrm{Mn}$ (IV) oxides. The modeling results show some interesting features as regards these results.

First, the calculations before addition indicate that the initial added $\mathrm{Mn}(\mathbb{I})$, should have precipitated as a higher oxidation state $\mathrm{Mn}$ oxide. Three $\mathrm{Mn}$ oxide phases were considered in the thermodynamic analysis $\mathrm{MnO}_{2}(\mathrm{c}), \mathrm{Mn}_{2} \mathrm{O}_{3}(\mathrm{c})$, and $\mathrm{Mn}_{3} \mathrm{O}_{4}(\mathrm{c})$. Of these, the model predicts the stability sequence $\mathrm{Mn}_{2} \mathrm{O}_{3}(\mathrm{c})>\mathrm{Mn}_{3} \mathrm{O}_{4}(\mathrm{c})>\mathrm{MnO}_{2}(\mathrm{c})$, indicating that the solutions are still at least partially reducing with respect to $\mathrm{Mn}$ (IV) oxides. This is also supported by the solution speciation results, which show a finite amount $(<0.5 \%)$ of $\mathrm{Mn}(\mathrm{II})$ in solution, principally tied up with the EDTA chelate. These calculations are not supported by the experimental data, which show that the initial added $\mathrm{Mn}$ does not precipitate. The solutions therefore appear to be somewhat more reducing than the calculations based solely upon $\mathrm{NO}_{2}^{-} / \mathrm{NO}_{3}^{-}$equilibria would indicate. Such effects are not unexpected given the significant concentrations of lower molecular weight organics that are present. These compounds can be effective reducing agents for the relatively small amounts of $\mathrm{Mn}$ present before addition ${ }^{1}$. To try and simulate this effect, the formation of all higher (i.e. oxidation state greater than II) Mn oxides was suppressed in the

\footnotetext{
${ }^{1}$ The importance of the low molecular weight organics in the $\mathrm{Mn}$ redox reactions is supported by the recent data of Hallen (personal communication) which shows that $\mathrm{MnO}_{4}{ }^{-}$reacts much more rapidly with formate than nitrite. The $\mathrm{MnO}_{4}^{-}$is thus more likely consumed by reactions with the lower molecular weight organics than by nitrite.
} 
calculations. In this simulation, the $\mathrm{Mn}$ remains in solution in the form of $\mathrm{Mn}$ (II) chelate complexes. If we ignore the possible reducing potential of the organic compounds, then the addition of $\mathrm{MnO}_{4}^{-}$does not result in any significant changes in the calculations since the $\mathrm{Mn}$ oxides are already stable in the $\mathrm{NO}_{2} \cdot \mathrm{NO}_{3}{ }^{-}$containing solutions. Under these conditions the added $\mathrm{MnO}_{4}{ }^{-}$simply oxidizes some $\mathrm{NO}_{2}^{-}$to $\mathrm{NO}_{3}^{-}$, raises the base concentration slightly, and precipitates the same higher $\mathrm{Mn}$ oxides in the same stability sequence as occurred before addition. This results because the added $\mathrm{MnO}_{4}^{-}$does not significantly alter the $\mathrm{NO}_{2}^{-} / \mathrm{NO}_{3}^{-}$ratio in solution. If the formation of the higher $\mathrm{Mn}$ oxides is suppressed, then the added $\mathrm{MnO}_{4}{ }^{-}$is now predicted to be reduced to $\mathrm{Mn}(\mathrm{II})$ by the $\mathrm{NO}_{2}$. Since stoichiometrically there is too little chelate to complex all of this additional $\mathrm{Mn}(\mathrm{II}), \mathrm{Mn}(\mathrm{OH})_{2}(\mathrm{c})$ now precipitates from solution. This precipitation also prevents the $\mathrm{Mn}(\mathrm{II})$ from competing effectively with the chelate complexes. So even under this extreme scenario it appears that the additional Mn does not serve as an effective competitor for displacing the other radionuclides/metals from chelate complexes.

\section{$3.6 \mathrm{Cr}$}

$\mathrm{Cr}$ was initially added to the simulant as sodium chromate. Modeling of the initial solutions indicates that given the $\mathrm{NO}_{2}{ }^{-} / \mathrm{NO}_{3}{ }^{-}$equilibria the $\mathrm{Cr}$ should remain as $\mathrm{CrO}_{4}{ }^{2-}$. No significant $\mathrm{Cr}$ (III) complexes, including hydrolysis species or chelate complexes are predicted to form at these high base concentrations. Recently, under an on-going EMSP project a preliminary equilibrium constant for a dimeric species $\left(\mathrm{Cr}_{2} \mathrm{O}_{2}(\mathrm{OH})_{4}{ }^{2}\right)$ has been proposed (D. Rai personal communication). However, even when this complex was tested, $\mathrm{CrO}_{4}^{2-}$ remains stable. The introduction of the $\mathrm{Sr}$ and permanganate does not alter this picture, $\mathrm{Cr}$ remains as $\mathrm{CrO}_{4}^{2}$. No precipitation equilibria were identified. 


\subsection{CONCLUSIONS AND RECOMMENDATIONS}

The most significant conclusion from this study that still requires resolution is that the TRU, $\mathrm{Fe}$, and $\mathrm{Cr}$ removal is most likely as a result of adsorption to the precipitated $\mathrm{Mn}$ oxides or $\mathrm{SrCO}_{3}(\mathrm{c})$. The mechanism does not appear to involve direct precipitation of hydroxide phases. The oxidizing properties of the $\mathrm{MnO}_{4}^{-}$do not appear to influence the process since the $\mathrm{NO}_{2}$; or low molecular weight organics, merely converts the $\mathrm{MnO}_{4}^{-}$to oxides. If this is true, then the addition of $\mathrm{MnO}_{4}^{-}$simply serves as a convenient way of adding $\mathrm{Mn}$ oxides. It would be of considerable interest to test this hypothesis by adding Mn oxides (of different composition) to the feed directly. This would test the adsorption hypothesis. Similar studies should be done with $\mathrm{SrCO}_{3}(\mathrm{c})$ to eliminate this is a removal vector. Unraveling these mechanisms is important if wastes of different $\mathrm{NO}_{2}{ }^{-}$concentration require treatment. If the $\mathrm{NO}_{2}{ }^{-}$concentration is too low, the Mn oxides may not form and the process would be ineffective. The thermodynamic models for $\mathrm{Eu}(\mathrm{III}) / \mathrm{Nd}(\mathrm{III})$ should also be tested in $\mathrm{NO}_{3}{ }^{-}, \mathrm{NO}_{2}{ }^{-}$, and $\mathrm{CO}_{3}{ }^{2-}$ containing systems to evaluate the importance of the mixing parameters in the Pitzer model and the possible formation of Eu-EDTA- $\mathrm{CO}_{3}{ }^{2-}$ complexes. Other than these issues, the modeling results agree well with the experimental findings of Hallen et al. (2000). Nevertheless, significant gaps remain in the experimental and thermodynamic data for application of these models. These data gaps include: undetermined or estimated ion interaction parameters, lack of ternary complexes for many of the metal-chelate-ligand complexes, and lack of information on partially decomposed chelates. Further experimental data with simplier waste simulants would also be extremely helpful in establishing the chemical mechanisms responsible for the observed decontamination factors. 


\subsection{REFERENCES}

Bruno, J., P. Wersin, and W. Stumm. (1992a). "On the Influence of Carbonate in Mineral Dissolution: $\mathrm{I}$. The Thermodynamics and Kinetics of Hematite Dissolution in Bicarbonate Solutions at $\mathrm{T}=25^{\circ} \mathrm{C}$." Geochimica Cosmochimica Acta 56, 1139-1147.

Bruno, J., P. Wersin, and W. Stumm. (1992b). "On the Influence of Carbonate in Mineral Dissolution: II. The Solubility of $\mathrm{FeCO}_{3}(\mathrm{~s})$ at $25^{\circ} \mathrm{C}$ and $1 \mathrm{~atm}$. Total Pressure." Geocbimica Cosmochimica Acta 56, 1149-1155.

Felmy, A.R., D.A. Dixon, Z. Wang, A.G. Joly, J.R. Rustad, and M.J. Mason. (2000). “The Aqueous Complexation of $\mathrm{Eu}(\mathrm{III})$ with Organic Chelates at High Base Concentration: Molecular and Thermodynamic Modeling Results.” ACS Symposium Series, The First Accomplishments of the Environmental Management Sciences Program (accepted).

Felmy, A.R., and D. Rai. (1999). “Application of Pitzer's Equations for Modeling the Aqueous Thermodynamics of Actinide Species: A Review." Journal of Solution Chemistry 28(5), 533-553. Special Memorial Edition in honor of Professor Kenneth Pitzer.

Felmy, A.R., and M.J. Mason. (1998). "The Displacement of Sr from Organic Chelates by Hydroxide, Carbonate, and Calcium in Concentrated Electrolytes." Joumal of Solution Chemistry 27(5), 435-454.

Felmy, A.R., D.A. Dixon, J.R. Rustad, M.J. Mason, and L.M. Onishi. (1998). “The Hydrolysis and Carbonate Complexation of Strontium and Calcium in Aqueous Electrolytes: Use of Molecular Modeling Calculations in the Development of Aqueous Thermodynamic Models." Joumal of Chemical Thermodynamics 30, 1103-1120.

Felmy, A.R., J.R. Rustad, M.J. Mason, and R. de la Bretonne. (1994a). "A Chemical Model for the Major Electrolyte Components of the Hanford Waste Tanks: The Binary Electrolytes in the System: $\mathrm{Na}-\mathrm{NO}_{3}-\mathrm{NO}_{2}-\mathrm{SO}_{4}-\mathrm{CO}_{3}-\mathrm{F}-\mathrm{PO}_{4}-\mathrm{OH}-\mathrm{Al}(\mathrm{OH})_{4}-\mathrm{H}_{2} \mathrm{O}$." TWRS-PP- 94-090. The Westinghouse Hanford Co., Richland, WA.

Felmy, A.R., C.C. Schroeder, L. Rao, D. Rai, M.J. Mason, and R.W. Fulton. (1994b). “Solubility Relations for Aqueous $\mathrm{Si}, \mathrm{Al}$, and $\mathrm{Cr}$ (III) Species in Concentrated Electrolytes: Development of Accurate Aqueous Thermodynamic Models.” Presented at the 208Th ACS National Meeting, Washington D.C., August 1994.

Felmy, A.R., and J.H. Weare. (1986). "The Prediction of Borate Mineral Equilibria in Natural Waters: Application to Searles Lake, California." Geochimica Cosmochimica Acta 50(12), 2771-2783.

Felmy, A. R., Dhanpat Rai, J. A. Schramke, and J. L. Ryan. 1989. "The Solubility of Plutonium Hydroxide in Dilute Solution and in High-Ionic Strength Chloride Brines." Radiochimica Acta 48:29-35. 
Hallen, R.T., P.R. Bredt, K.P. Brooks, and L.K. Jagoda. (2000). “Combined Entrained Solids and Sr/TRU Removal from AN-107 Diluted Feed.” BNFL-RPT-027.

Harvie, C.E., N. Møller, and J.H. Weare. (1984). "The Prediction of Mineral Solubilities in Natural Waters: The Na-K-Mg-Ca-H-Cl-SO $-\mathrm{OH}-\mathrm{HCO}_{3}-\mathrm{CO}_{3}-\mathrm{CO}_{2}-\mathrm{H}_{2} \mathrm{O}$ System to High Ionic Strengths at $25^{\circ} \mathrm{C} . "$ Geochimica Cosmocbimica Acta 48(4), 723-751.

Martell, R.E., and R.M. Smith. (1995). Critically Selected Stability Constants of Metal Complexes Database, Version 2.0. NIST Standard Reference Data Program, Gaithersburg, MD.

Mattigod, S.V., D. Rai, A.R. Felmy, and L. Rao (1997). Solubility and Solubility Product of Crystalline $\mathrm{Ni}(\mathrm{OH})_{2}$. J. Solution Chemistry, 26 (4), 391-403.

OLI Systems, Inc. (1999). Environmental Simulation Program, ver. 6.2, Aug. 2, 1999

Pitzer, K.S. (1991). Activity Coefficients in Electrolyte Solutions. $2^{\text {nd }}$ edition. CRCPress, Boca Raton, FL, 542 pp.

Pitzer, K.S. (1973). "Thermodynamics of Electrolytes. I. Theoretical Basis and General Equations." Journal of Physical Chemistry 77(2), 268-277.

Pokrovsky, O.S., M.G. Bronikowski, R.C. Moore, G.R. Choppin. (1998). "Interaction of Neptunyl(V) nad Uranyl(VI) with EDTA in $\mathrm{NaCl}$ Media: Experimental Study and Pitzer Modeling." Radiocbimica Acta 80, 23-29.

Rai, D., A.R. Felmy, and R.W. Szelmeczka. (1991a). "Hydrolysis Constants and Ion-Interaction Parameters for $\mathrm{Cd}(\mathrm{II})$ in Zero to High Concentrations of $\mathrm{NaOH}-\mathrm{KOH}$ and the Solubility Product of $\mathrm{Cd}(\mathrm{OH})_{2}$ (c)." Journal of Solution Chemistry 20, 375-390.

Rai, D., A.R. Felmy, and D.A. Moore. (1991b). "Thermodynamic Model for Aqueous $\mathrm{Cd}^{2+}-\mathrm{CO}_{3}^{2-}$ Ionic Interactions in High-ionic-strengh Carbonate Solutions, and the Solubility Product of Crystalline $\mathrm{CdCO}_{3}$." Journal of Solution Chemistry 20(12), 1169-1187.

Rao, L., D. Rai, A.R. Felmy, R.W. Fulton and C.F. Novak. (1996a). "Solubility of $\mathrm{NaNd}\left(\mathrm{CO}_{3}\right)_{2} \cdot 6 \mathrm{H}_{2} \mathrm{O}$ in Concentrated $\mathrm{Na}_{2} \mathrm{CO}_{3}$ and $\mathrm{NaHCO}_{3}$ Solutions." Radiochemica Acta 75, 141-147.

Rao, L., D. Rai, and A.R. Felmy. (1996b). "Solubility of $\mathrm{Nd}(\mathrm{OH})_{3}{ }^{\circ}$ in $0.1 \mathrm{M} \mathrm{NaCl}$ Aqueous Solution at $25^{\circ} \mathrm{C}$ and $90^{\circ} \mathrm{C}$." Radiochemica Acta 72, 151-155.

SRTC. 1999. TRU Removal from Hanford AN-107 Simulant using Sodium Permanganate and Calcium, October 1999, BNF-003-98-0160, SRTC, Aiken, South Carolina. 
PNWD-3044

BNFL-RPT-037 Rev. 0

\section{DISTRIBUTION}

No. of

Copies

OFFSITE
No. of

Copies

ONSITE
2 DOE/Office of Scientific and Technical 5 Information

1 Charles Nash Westinghouse Savannah River Company 1 Savannah River Technology Center PO Box 616, Road 1 Aiken, SC 29802
British Nuclear Fuels, Limited M. E. Johnson (4) BN-FL

A. Thompson BN-FL

Fluor Daniel Northwest G. T. McLean

G3-10

2 Lockheed Martin Hanford Company

T. W. Crawford

R3-73

D. J. Washenfelder

H6-18

2 Numatec Hanford Company

R. A. Kirkbride

R3-73

R. M. Orme

R3-73

12 Pacific Northwest National Laboratory
A. R. Felmy (5)
K8-96
R. T. Hallen
K2-12
E. V. Morrey
P7-28
Technical Report Files (5) K1-06

Distr. 1 